\title{
Sedimentation Survey of Lago Guayo, Puerto Rico, October 1997
}

- Water-Resources Investigations Report 99-4053 


\section{Sedimentation Survey of Lago Guayo, Puerto Rico, October 1997}

By Luis R. Soler-López

Water-Resources Investigations Report 99-4053

In cooperation with the PUERTO RICO ELECTRIC POWER AUTHORITY 


\section{U.S. DEPARTMENT OF THE INTERIOR BRUCE BABBITT, Secretary}

\section{U.S. GEOLOGICAL SURVEY}

Charles G. Groat, Director

Use of trade names in this report is for identification purposes only and does not imply endorsement by the U.S. Government.

For additional information write to:

Copies of this report can be purchased from:

District Chief

U.S. Geological Survey

GSA Center, Suite 400-15

U.S. Geological Survey

651 Federal Drive

Branch of Information Services

Box 25286

Guaynabo, Puerto Rico 00965-5703

Denver, C0 80225-0286 


\section{CONTENTS}

Abstract

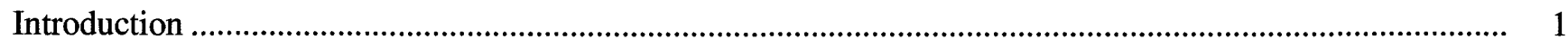

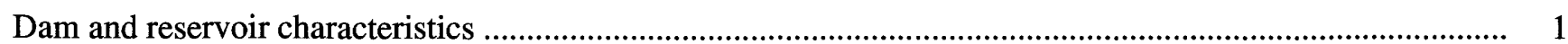

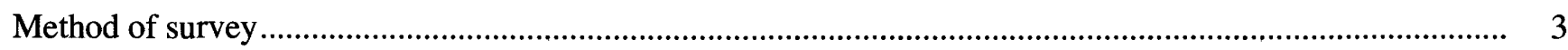

Field techniques

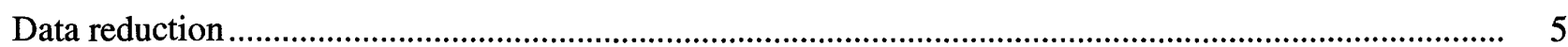

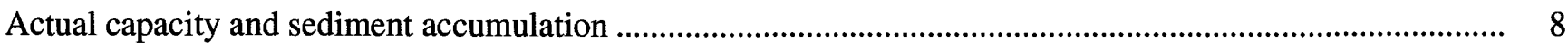

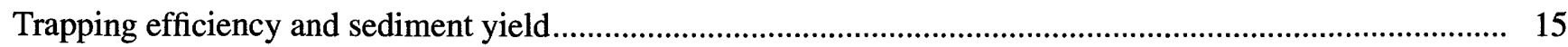

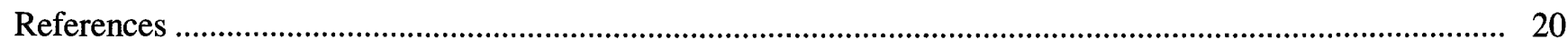

\section{PLATE}

[Plate is in pocket]

1. Lago Guayo, Puerto Rico, Bathymetry, October 1997 


\section{FIGURES}

1.-4. Map showing:

1. Location of Lago Guayo in the Río Grande de Añasco basin, Puerto Rico.

2. Planned cross-section locations for the October 1997 bathymetric survey of Lago Guayo, Puerto Rico

3. Location of model cross sections of the October 1997 bathymetric survey of Lago

Guayo, Puerto Rico

4. Actual track lines of the October 1997 bathymetric survey of Lago Guayo, Puerto Rico

5. Model cross sections generated from TIN surface model of Lago Guayo, Puerto Rico, for the 1997 bathymetric survey

6. Map showing reference distances for longitudinal profiles of Lago Guayo, Puerto Rico, during the October 1997 bathymetric survey.

7. Longitudinal profiles generated from the 1997 TIN surface model of Lago Guayo, Puerto Rico, along the different routes of the reservoir

8. Capacity curve for Lago Guayo, Puerto Rico, for 1997

\section{TABLES}

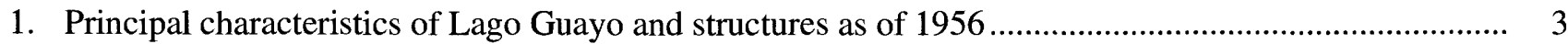

2. Comparison of the 1956 and 1997 sedimentation surveys of Lago Guayo, Puerto Rico ...................... 8 


\begin{tabular}{rll}
\hline Multiply & By & To obtain \\
centimeter & Length & \\
meter & 0.03281 & foot \\
millimeter & 3.281 & foot \\
kilometer & 0.03937 & inch \\
& 0.6214 & mile \\
square meter & Area & \\
square kilometer & 10.76 & square foot \\
square kilometer & 0.3861 & square mile \\
& 247.1 & acre \\
cubic meter & Volume & \\
million cubic meters & 35.31 & cubic foot \\
cubic meter & 810.7 & acre-foot \\
& 0.0008107 & acre-foot \\
Colume per unit time (includes flow) & \\
cubic meter per second & 35.31 & cubic feet per second \\
gram per cubic centimeter & 15,850 & gallon per minute \\
megagram per square kilometer & 62.43 & pound per cubic foot
\end{tabular}

Horizontal Datum - Puerto Rico Datum, 1940 Adjustment

Sea level: In this report, "sea level" refers to the National Geodetic Vertical Datum of 1929 (NGVD of 1929)-a geodetic datum derived from a general adjustment of the first-order level nets of both the United States and Canada, formerly called "Sea Level Datum of 1929."

\section{Acronyms used in this report:}

BLASS Bathymetric/Land Survey System

DGPS Differential Global Positioning System

GIS Geographic Information System

PREPA Puerto Rico Electric Power Authority

TIN Triangulated Irregular Network

USGS U.S. Geological Survey 


\title{
Sedimentation Survey of Lago Guayo, Puerto Rico, October 1997
}

\author{
By Luis R. Soler-López
}

\section{Abstract}

A bathymetric survey of Lago Guayo was conducted during October 1997 to determine the storage capacity, the amount and location of the sediment accumulated, the sedimentation rate of the reservoir, and to estimate the trapping efficiency of the reservoir and the sediment yield of the basin. The existing storage capacity was calculated to be 16.57 million cubic meters. About 2.63 million cubic meters of sediment has accumulated in the reservoir in 41 years. This amounts to an average long-term sedimentation rate of about 0.06 million cubic meters per year, or an average 0.3 percent of capacity loss per year. The average trapping efficiency was estimated to be about 97 percent and the sediment yield of the reservoir basin is about 857 megagrams per square kilometer per year. At this sedimentation rate, the reservoir has a useful life of about 276 more years.

\section{INTRODUCTION}

The Puerto Rico Electric Power Authority (PREPA) operates the Southwestern Puerto Rico Project that consists of a series of reservoirs connected by underground tunnels to provide water for irrigation and hydroelectric power generation. Lago Guayo is the largest reservoir in the project and originally provided about 19.20 million cubic meters of water (Puerto Rico Water Resources Authority, 1980).

The high average annual rainfall $(2,290$ millimeters) (Calvesbert, 1970) combined with the agricultural land use of the area results in large amounts of sediment being transported and deposited in the reservoir, depleting the available storage capacity of Lago Guayo. Also, Lago Yahuecas, another reservoir in the project, has a very low trapping efficiency, resulting in the diversion of significant amounts of sediment into Lago Guayo.

During October 29 to 30, 1997, the U.S. Geological Survey (USGS) in cooperation with the PREPA conducted a bathymetric survey of Lago Guayo to assess the magnitude of sedimentation in the reservoir. Time-tagged position data were collected using a differential global positioning system (DGPS) and recorded along with digital depth-sounder data into a computer hard disk. Depth soundings were also recorded on an annotated paper chart for archiving and to provide ancillary data to facilitate the editing of the digital data. The digital data were transferred into a geographic information system (GIS) for processing and analysis, giving the storage capacity and the sediment accumulation in the reservoir.

\section{DAM AND RESERVOIR CHARACTERISTICS}

Lago Guayo is located on the Río Guayo in west-central Puerto Rico, about 12.5 kilometers west of the town of Adjuntas and about 3.5 kilometers north of the village of Castañer (fig. 1). The reservoir is the largest in the Southwestern Puerto Rico Project and originally provided 19.20 million cubic meters of storage capacity for irrigation and hydroelectric power generation (Puerto Rico Water Resources Authority, 1980). 


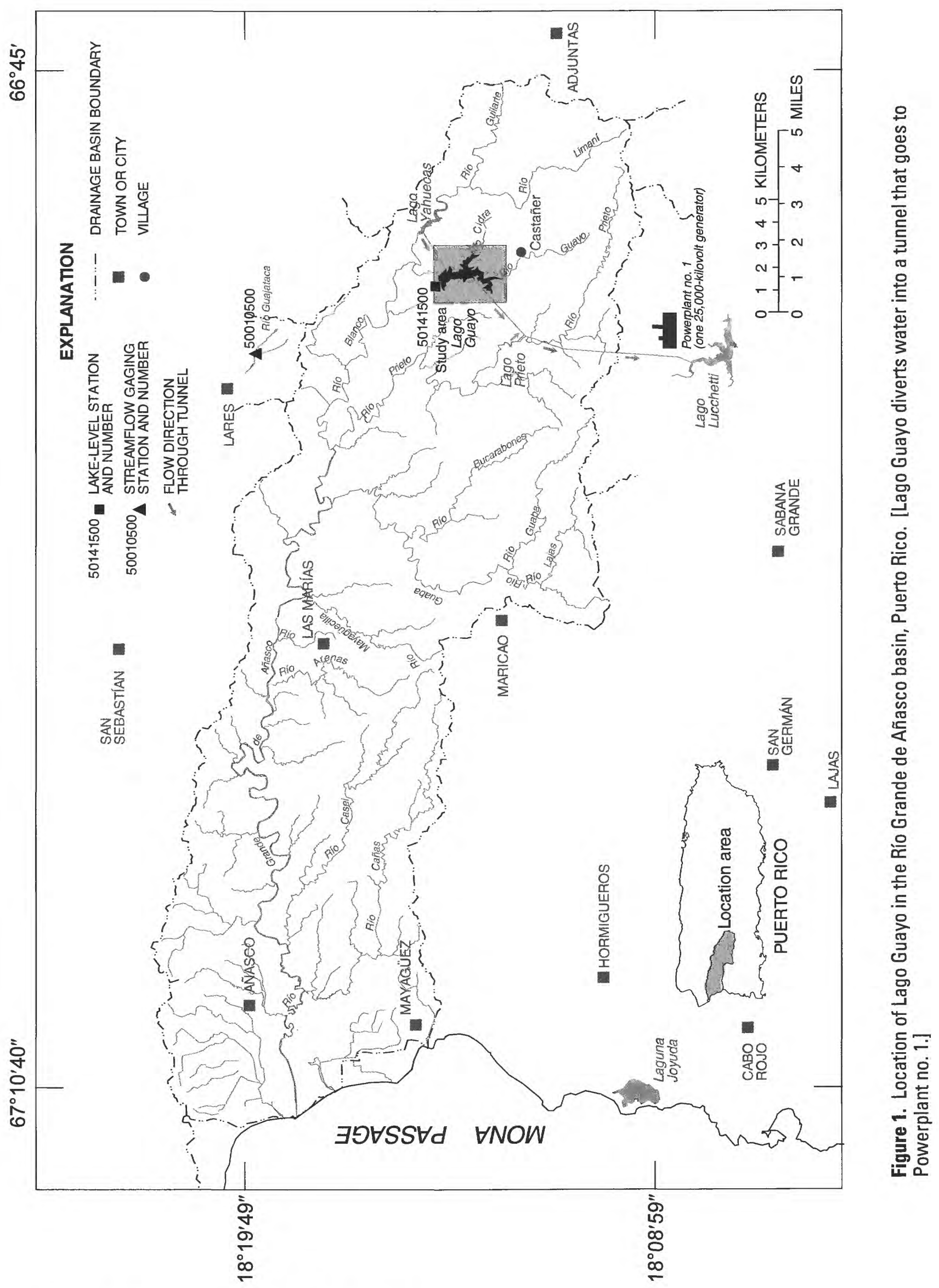


The dam is a concrete gravity structure with a total length of 169.16 meters, a structural height of 57.91 meters, and a base width of 44.20 meters. The nonoverflow sections of the dam are at an elevation of 448.05 meters above mean sea level, the maximum storage elevation. An ungated overflow spillway measuring 67.06 meters in length is centrally located between the nonoverflow sections and has an elevation of 445.00 meters above mean sea level. A 0.61-meter diameter sluiceway, located in the spillway section and protected by a concrete trash rack structure, has an elevation of 406.61 meters above mean sea level.

An unlined 10.9-kilometer-long power tunnel diverts water from Lago Guayo to a surge chamber located about 900 meters upstream of Powerplant no. 1 (Sheda and Legas, 1968). The inlet structure of the Guayo tunnel is located on the left shore near the upper reach of the reservoir, and has an elevation of 417.58 meters above mean sea level. Releases to the tunnel are controlled by a 1.07-meter cast iron slide gate. The principal characteristics of Lago Guayo and structures are presented in table 1.

\section{METHOD OF SURVEY}

The bathymetric survey of Lago Guayo involved planning, data collection, data processing and analysis. A geographic information system, Arc/Info, served as the database for pre-survey planning and to analyze the collected data. Cross sections were planned at a spacing of 50-meter intervals, starting at the dam and continuing upstream to the river deltas (fig. 2). Bathymetric data were collected using a depth sounder coupled to a DGPS to control the horizontal position of the survey boat. The collected depth data were converted to equivalent depths below spillway by using lake stage observations made at the USGS lake-level station Lago Guayo at Damsite near Castañer (station number 50141500) (fig. 1).

Table 1. Principal characteristics of Lago Guayo and structures as of 1956 (Modified from Sheda and Legas, 1968) [Elevations in meters above mean sea level]

Total length of dam at top (spillway and nonoverflow sections) 169.16 meters

Length of spillway 67.06 meters

Elevation of crest of spillway .445 .00 meters

Maximum width at base 44.20 meters

Maximum flood-level storage. 23.44 million cubic meters

Spillway crest-level storage 21.46 million cubic meters

Diameter of sluiceway .0 .61 meter

Maximum height of dam .57 .91 meters

Elevation of inlet structure of Guayo tunnel. .417 .58 meters

Drainage area at dam site. 24.86 square kilometers 


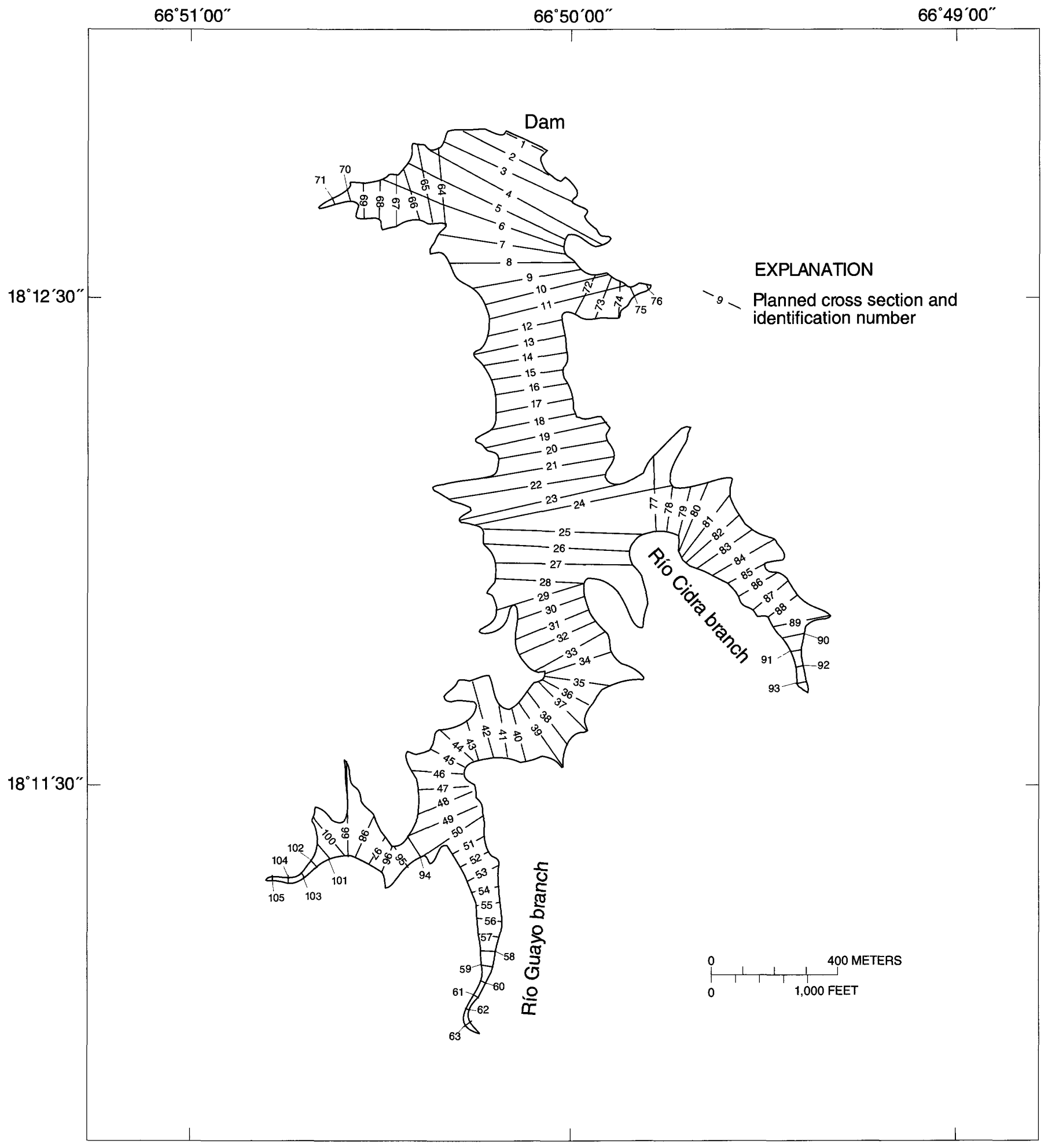

Figure 2. Planned cross-section locations for the October 1997 bathymetric survey of Lago Guayo, Puerto Rico. 
Contour lines of equal depth were drawn at variable intervals from the shoreline to the deepest part of the reservoir. A contour line representing the deepest part of the reservoir ( 38.5 meters) was also added. These contour lines were then converted into a triangulated irregular network (TIN) describing the surface model of the reservoir. From this model, the reservoir storage capacity and the volume of sediment accumulated since impoundment were calculated.

A stage-storage curve was developed by calculating the reservoir volume at incremental pool elevations. Also, longitudinal profiles representing the reservoir bottom along the thalweg of the different routes, and cross sections representing the reservoir bottom from shoreline to shoreline were developed from the TIN surface model. These cross sections will be referred to as model cross sections later in this report. The locations of the model cross sections are presented in figure 3 .

\section{Field Techniques}

The bathymetric survey of Lago Guayo took place during October 29 to 30, 1997. Data were collected using the Bathymetric/Land Survey System (BLASS) developed by Specialty Devices, Inc. This system, consisting of two Motorola Six Gun DGPS units, indicates the horizontal position of the survey boat. The units were used in static mode before the bathymetric survey started to establish reference marks at several sites overlooking the reservoir. Three reference marks were established from the USGS benchmark HELECHO (lat $18^{\circ} 14^{\prime} 45.370^{\prime \prime} N$., long $66^{\circ} 48^{\prime} 41.836^{\prime \prime W}$.); Guayo-1 (lat $18^{\circ} 11^{\prime} 50.534^{\prime \prime N}$., long $66^{\circ} 50^{\prime} 02.404^{\prime \prime} \mathrm{W}$.), at the boat ramp of the Lago Guayo Fishing Club; Guayo-2 (lat $18^{\circ} 12^{\prime} 46.083^{\prime \prime N}$., long $66^{\circ} 50^{\prime} 08.815^{\prime \prime} \mathrm{W}$.), at the stairs on the left parapet of the dam; and Guayo-3 (lat $18^{\circ} 12^{\prime} 38.925^{\prime \prime}$., long $66^{\circ} 50^{\prime} 06.884^{\prime \prime} \mathrm{W}$.), at the left abutment of the dam.

These sites later served as reference or master stations. One DGPS unit was installed at the reference station whereas the other DGPS unit was mounted on the survey boat to be used as the mobile unit. The DGPS on the survey boat independently calculated a position every second, while a set of pseudo-range corrections were received every 5 seconds from the reference station to maintain positional precision within 2 meters. When reception of the reference station corrections was lost, a new reference station was occupied or a signal repeater was installed.

Water depths were measured by using a Raytheon DE-719 depth sounder with an Odom Digitrace that converts the depth data into digital form, to be stored in a portable computer. The depth recorder was bar checked at a 30-meter depth. A bar check is used to calibrate the depth sounder by lowering a metal plate or bar to a known depth and verifying the analog values recorded on the chart and the digital values recorded on the computer. A tolerance of 5 centimeters was used. Navigation was controlled by the bathymetric survey software HYPACK, which receives and records positions and depths once every second while in survey mode.

Although 105 cross sections were planned in the office, only 95 cross sections were surveyed. Ten sections were inaccessible because of low water depths or because floating debris impeded navigation. The track lines of the October 1997 bathymetric survey are shown in figure 4.

\section{Data Reduction}

Initial editing with verification of the positional and depth data was performed by using the HYPACK software. Positions were corrected to eliminate the anomalous positional errors that appear when the correction signal is lost due to either local topographic features or electromagnetic interference. Water-depth readings were corrected in HYPACK to eliminate anomalous depth values that did not appear on the fathometer chart.

The pool elevation during the 2 days of the bathymetric survey slightly decreased. To report the depth data collected as depths below spillway elevation, a time-elevation correction factor was applied. Continuous measurement of the pool elevation during the bathymetric survey were obtained from the Lago Guayo at damsite near Castañer lakelevel station. 


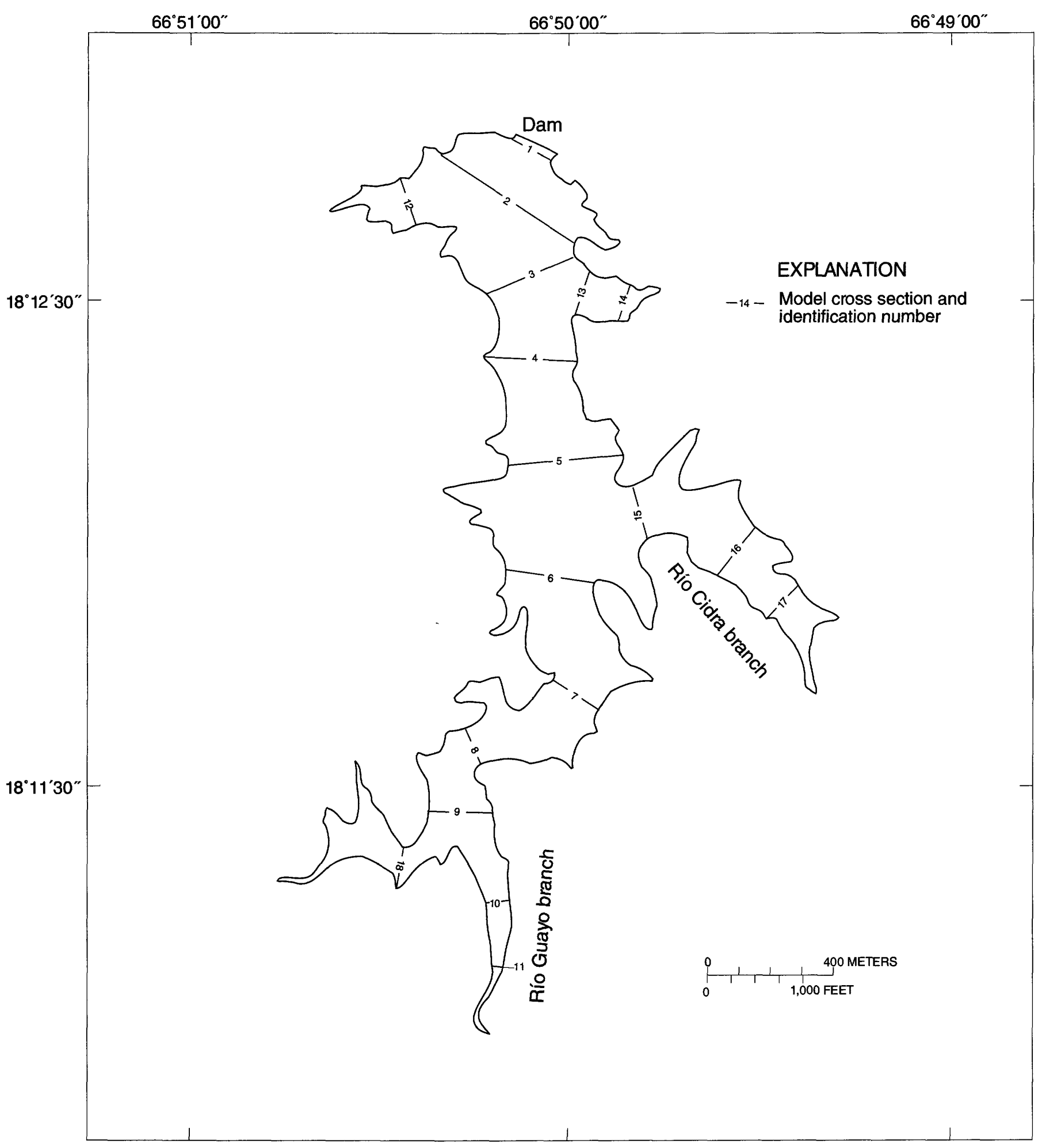

Figure 3. Location of model cross sections of the October 1997 bathymetric survey of Lago Guayo, Puerto Rico. 


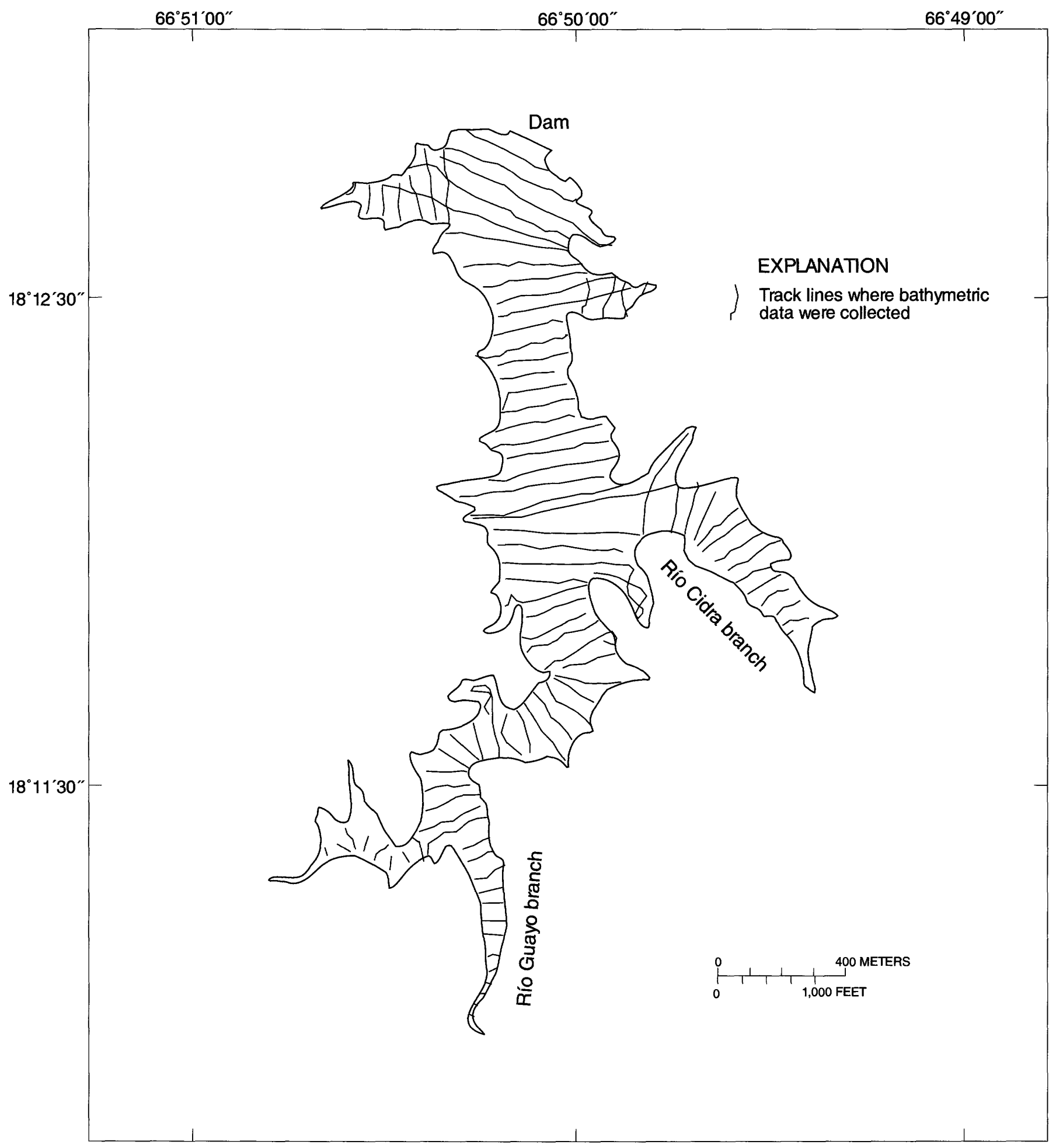

Figure 4. Actual track lines of the October 1997 bathymetric survey of Lago Guayo, Puerto Rico. 
The edited data were then transferred into the GIS. Contour lines were drawn by using the software Arc/Info (plate 1). The program was customized to color code the different depth intervals. Contour lines were then drawn using heads-up digitizing. The contour map was used to construct the TIN surface model of the reservoir bottom.

The storage capacity and sediment accumulation were calculated using the TIN surface model of the reservoir. Model cross sections and longitudinal profiles were generated from the TIN surface model to show the lake bottom morphology for different areas of the lake.

\section{ACTUAL CAPACITY AND SEDIMENT ACCUMULATION}

The capacity of Lago Guayo was calculated to be 16.57 million cubic meters in 1997 . This represents a reduction of 14 percent or 2.63 million cubic meters from the original storage capacity in 1956. This amounts to an average long-term sedimentation rate of 0.06 million cubic meters per year or an average 0.3 percent of capacity loss per year. At this sedimentation rate the expected useful life of Lago Guayo is about 276 more years. This estimate is likely to change, since the trapping efficiency decreases as the reservoir fills with sediment. The results of the 1956 and 1997 bathymetric surveys are summarized in table 2 .

The elevation of the inlet structure of the Guayo tunnel is of 417.58 meters above mean sea level. The live storage of the reservoir was determined by calculating the volume of the TIN surface model at the specified datum. Of the 16.57 million cubic meters of storage capacity, only 15.71 million cubic meters is available for hydroelectric power generation. The remaining 0.86 million cubic meters represents dead storage that serves as a depository for future sediment accumulation. Model cross sections generated from the TIN surface model of the reservoir are shown in figure 5 .

Table 2. Comparison of the 1956 and 1997 sedimentation surveys of Lago Guayo, Puerto Rico

[---, not available or undetermined]

\begin{tabular}{lcc}
\hline & 1956 & 1997 \\
\hline Total capacity, in million cubic meters & 19.20 & 16.57 \\
Live storage, in million cubic meters & -- & 15.71 \\
Dead storage, in million cubic meters & --- & 0.86 \\
Sediment accumulated, in million cubic meters & 0 & 2.63 \\
Years since construction & 0 & 41 \\
Storage loss, in percent & 0 & 14 \\
Average annual capacity loss, in percent & 0 & 0.3 \\
Average long-term sedimentation rate, in million cubic meters per year & 0 & 0.06 \\
Year reservoir is expected to completely fill with sediment ${ }^{1}$ & --- & 2273 \\
Trapping efficiency, in percent & 298 & 96 \\
Average sediment yield, in megagrams per square kilometer per year ${ }^{3}$ & $-\cdots$ & 857 \\
\hline
\end{tabular}

${ }^{1}$ Assuming that the reservoir would continue to fill at the average long-term sedimentation rate; in reality, sedimentation rate decreases with time as the reservoir fills and the trapping efficiency decreases.

${ }^{2}$ Using the capacity/inflow ratio described by Brune (1953).

${ }^{3}$ Including the Lago Yahuecas drainage area. Lago Yahuecas diverts water into Lago Guayo, exporting considerable amounts of sediments into Lago Guayo. 

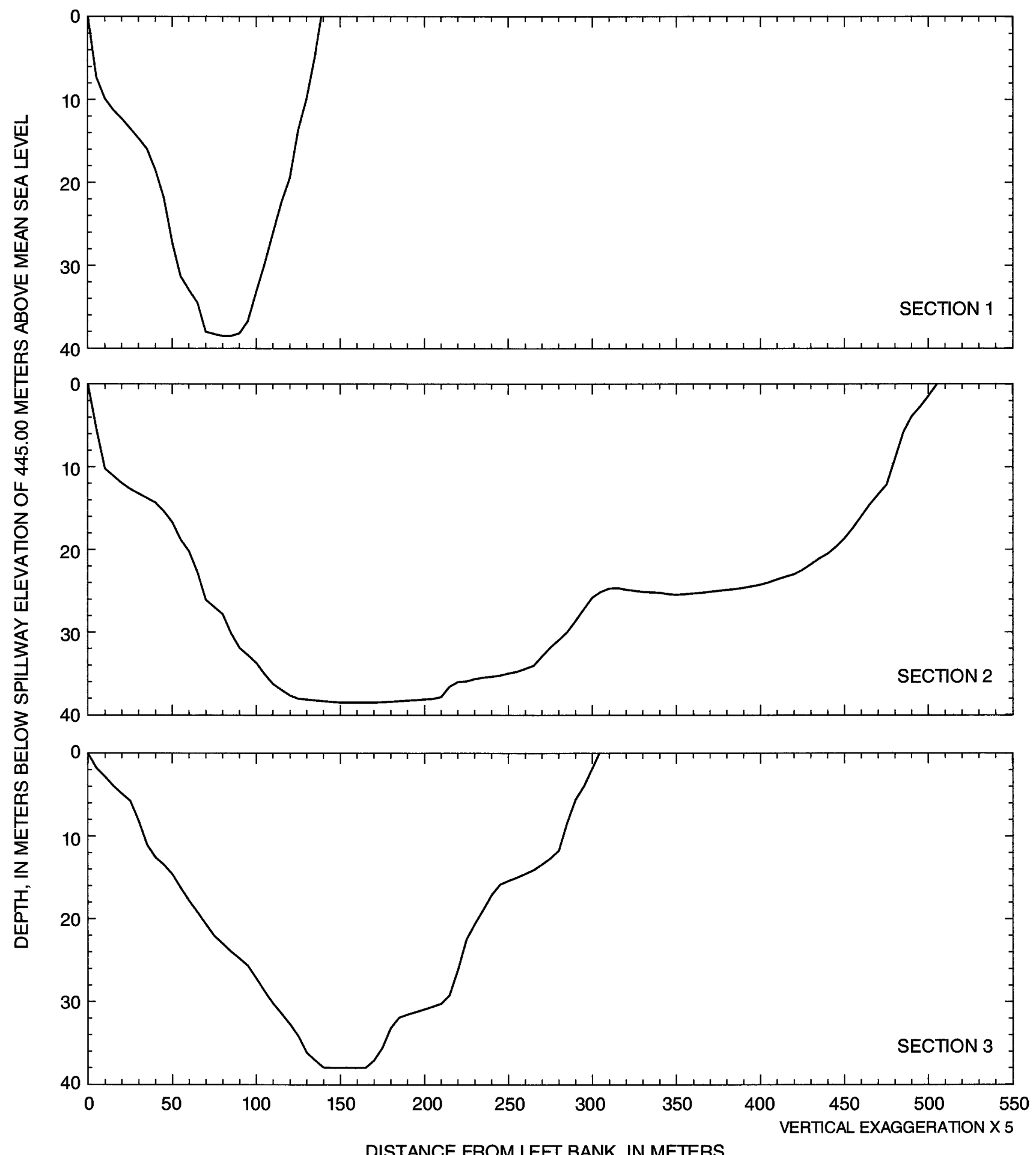

Figure 5. Model cross sections generated from TIN surface model of Lago Guayo, Puerto Rico, for the 1997 bathymetric survey. [Cross sections are oriented with the observer looking in the downstream direction. Refer to fig. 3 for cross-section locations and to fig. 6 for the reference distances.] 

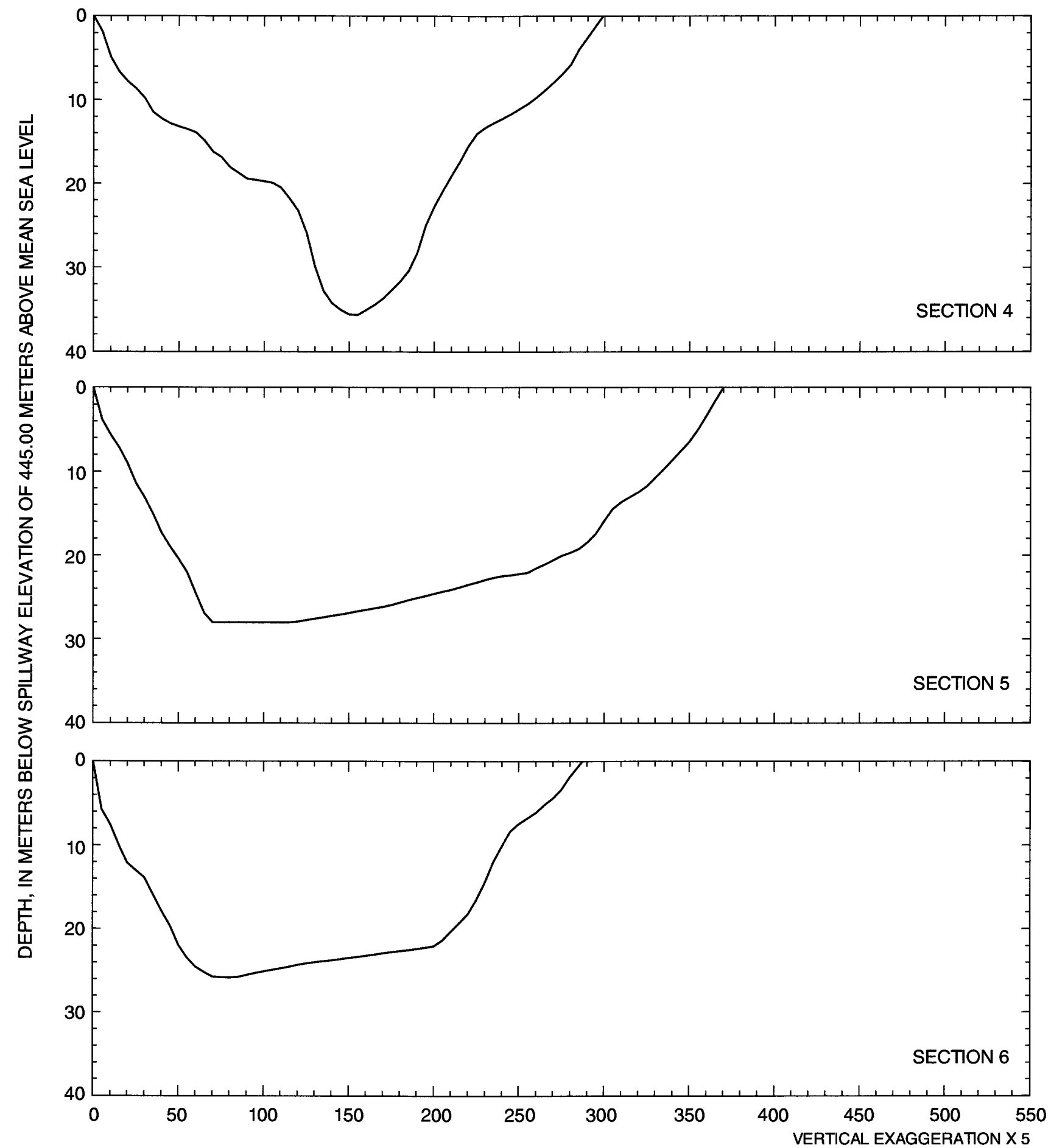

DISTANCE FROM LEFT BANK, IN METERS

Figure 5. Model cross sections generated from TIN surface model of Lago Guayo, Puerto Rico, for the 1997 bathymetric survey-Continued. [Cross sections are oriented with the observer looking in the downstream direction. Refer to fig. 3 for cross-section locations and to fig. 6 for the reference distances.] 


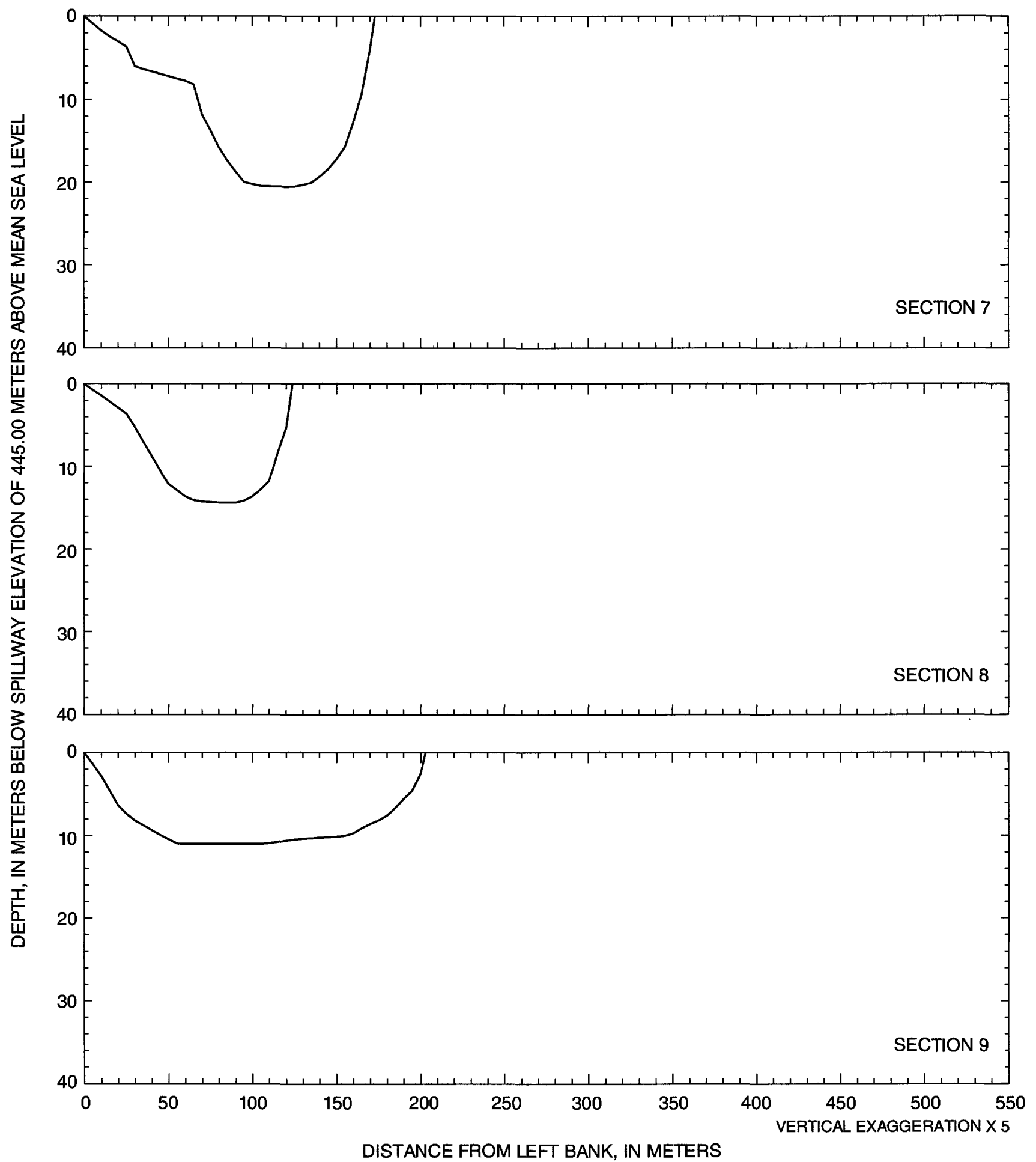

Figure 5. Model cross sections generated from TIN surface model of Lago Guayo, Puerto Rico, for the 1997 bathymetric survey - Continued. [Cross sections are oriented with the observer looking in the downstream direction. Refer to fig. 3 for cross-section loc ations and to fig. 6 for the reference distances.] 

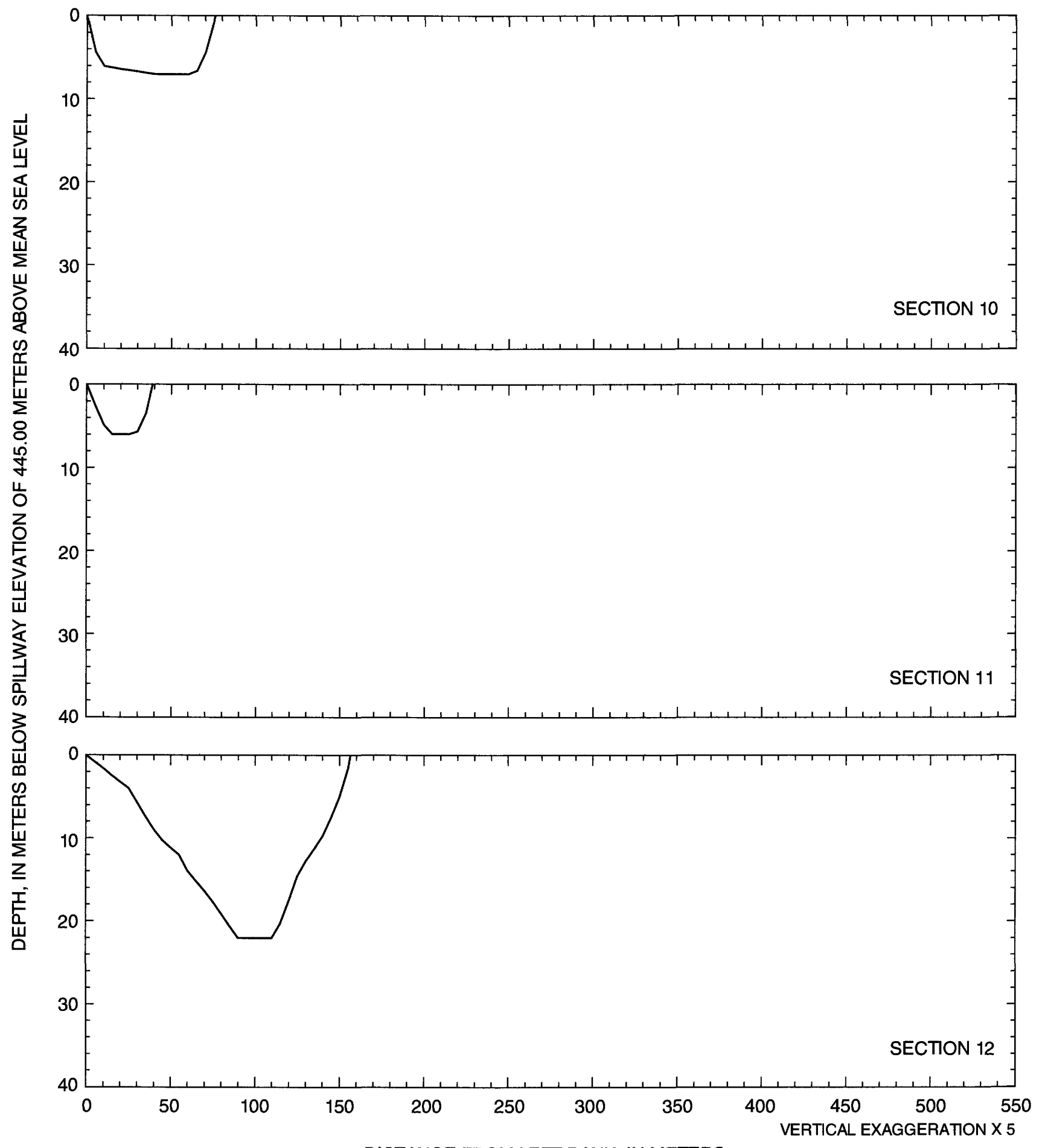

DISTANCE FROM LEFT BANK, IN METERS

Figure 5. Model cross sections generated from TIN surface model of Lago Guayo, Puerto Rico, for the 1997 bathymetric survey-Continued. [Cross sections are oriented with the observer looking in the downstream direction. Refer to fig. 3 for cross-section locations and to fig. 6 for the reference distances.] 


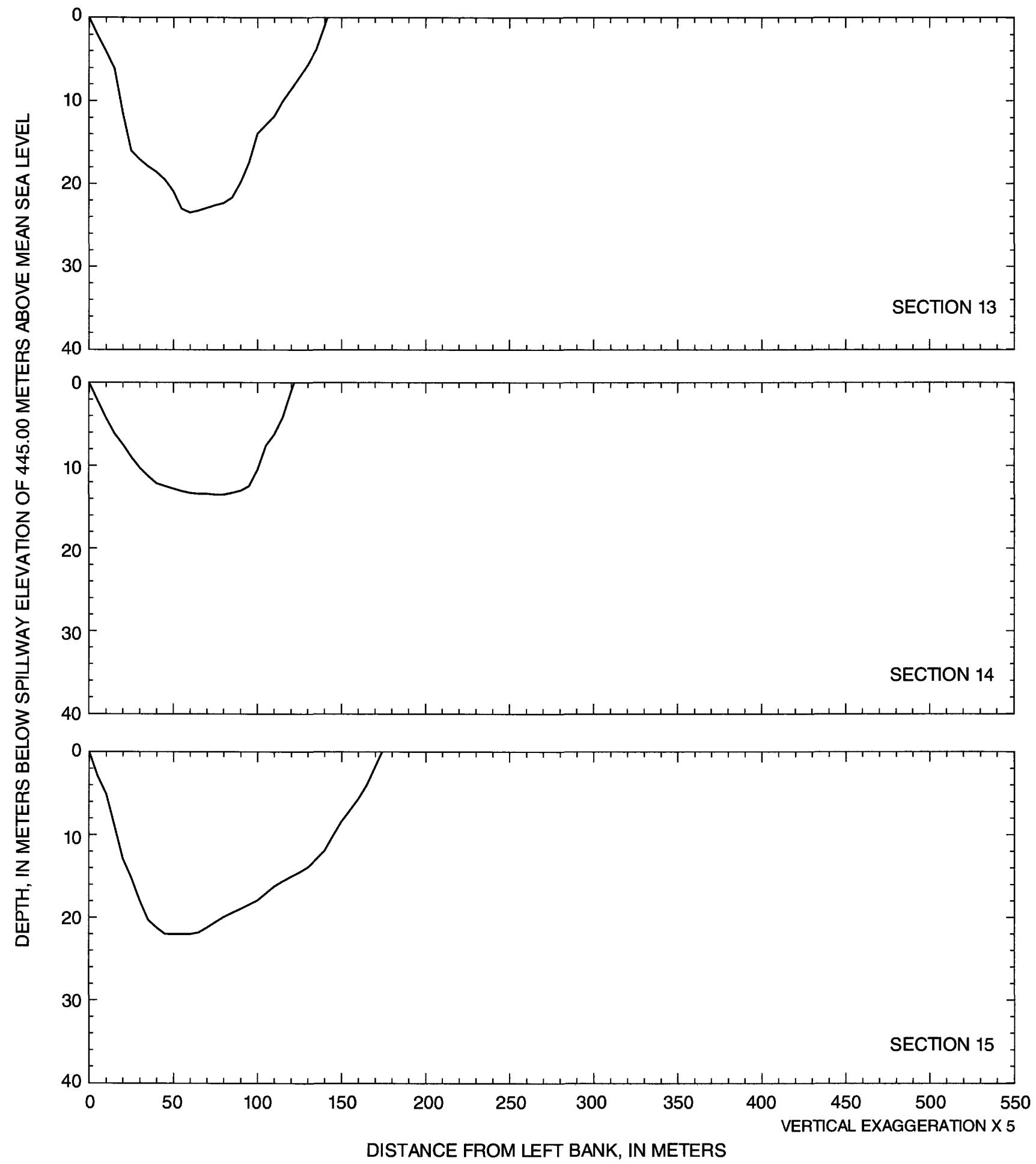

Figure 5. Model cross sections generated from TIN surface model of Lago Guayo, Puerto Rico, for the 1997 bathymetric survey-Continued. [Cross sections are oriented with the observer looking in the downstream direction. Refer to fig. 3 for cross-section locations and to fig. 6 for the reference distances.] 

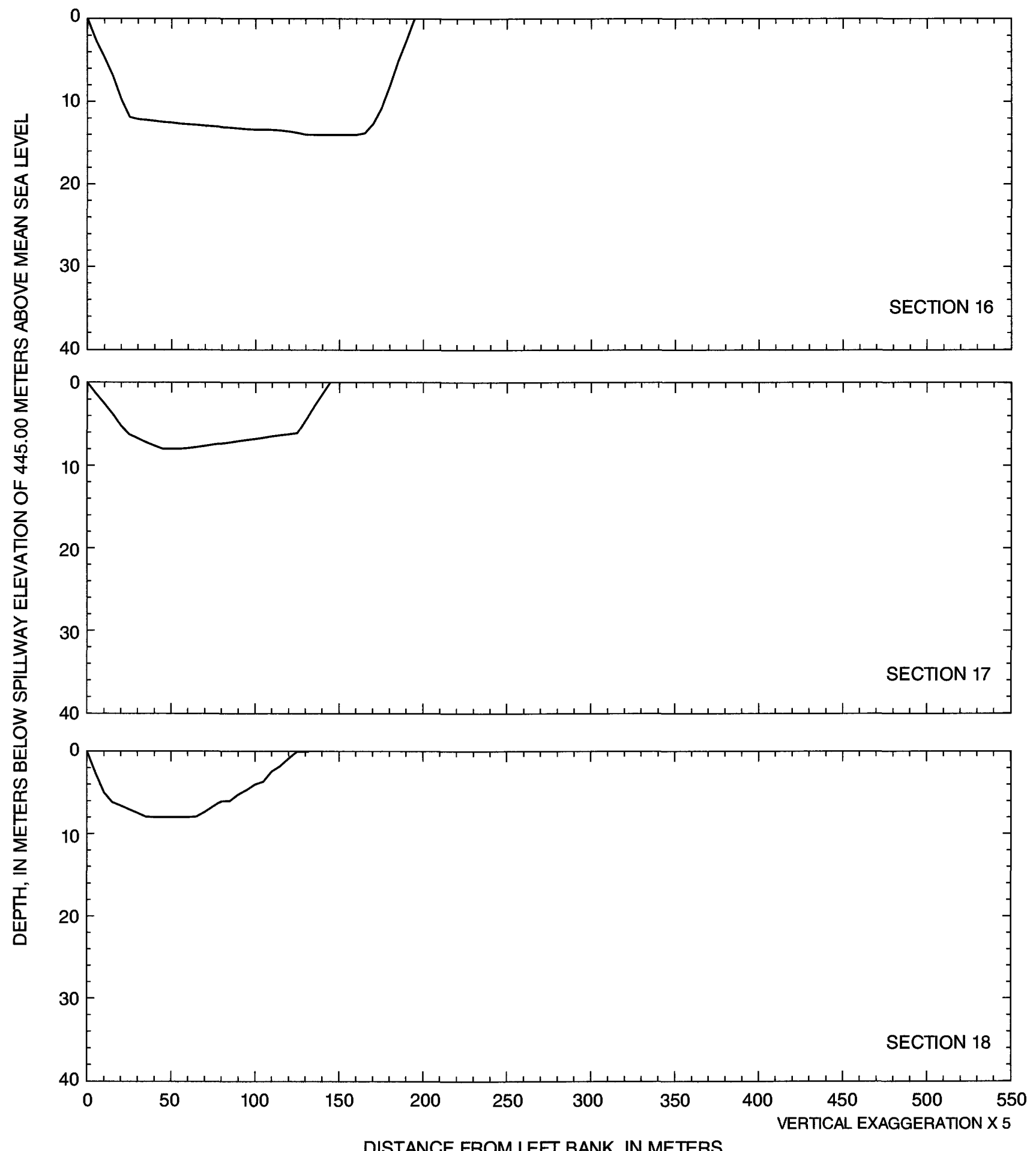

Figure 5. Model cross sections generated from TIN surface model of Lago Guayo, Puerto Rico, for the 1997 bathymetric survey-Continued. [Cross sections are oriented with the observer looking in the downstream direction. Refer to fig. 3 for cross-section locations and to fig. 6 for the reference distances.] 
Sediment accumulation in the reservoir appears to be moderate, since the model cross sections in the dam area (fig. 5) do not show the flat bottom usually present in severely sedimented reservoirs. A flat bottom is only observed upstream from the confluence of the Río Cidra and Río Guayo branches of the reservoir.

The Guayo tunnel intake structure is about 1,500 meters upstream from the dam (fig. 6). It is likely that the reservoir bottom in the adjacent area of the tunnel inlet hoist house has reached the elevation of the inlet structure trash rack. The structure is submerged at a water depth of about 27 meters, and the reservoir bottom surrounding this area has a maximum depth of about 26 meters. It is possible that if the structure is not operated on a regular basis it could be buried under deposited material since it is located near the confluence of the Río Cidra and the Río Guayo branches of the reservoir. The reservoir bottom in the dam area has reached an elevation of about 406.5 meters above mean sea level. This means that the sluiceway structure, which is at an invert elevation of 406.61 meters above mean sea level and has an opening 0.61 meter in diameter, is also in danger of being disabled by sediment deposition.

The longitudinal profiles along the thalweg of the different routes of Lago Guayo generated from the TIN surface model of the reservoir are shown in figure 7. A capacity curve was generated from the 1997 TIN surface model (fig. 8).

\section{TRAPPING EFFICIENCY AND SEDIMENT YIELD}

The trapping efficiency of Lago Guayo was estimated by using the capacity/inflow ratio described by Brune (1953). Since the Lago Guayo basin has no stream-gaging station to measure the reservoir inflow, the drainage-basin runoff was estimated by using the mean annual rainfall of 2,290 millimeters (Calvesbert,
1970) and the rainfall/runoff ratio of 0.45 (Giusti and López, 1967) for this particular basin. Multiplying the average annual rainfall by the rainfall/runoff ratio gives a mean annual runoff of 1.03 meters for the Lago Guayo basin. Based on the 24.86-square-kilometer catchment of Lago Guayo, the average annual runoff entering the reservoir is 25.61 million cubic meters per year. From Brune's curve, the trapping efficiency of Lago Guayo was estimated to be about 98 percent in 1956 and about 96 percent for 1997 . The average trapping efficiency is about 97 percent.

The Lago Guayo basin was artificially increased when Lago Yahuecas was connected to Lago Guayo by an underground tunnel connection, to provide additional water supply for hydroelectric power generation at Powerplant no. 1 (fig. 1). Lago Yahuecas is a reservoir that is part of the Southwestern Puerto Rico Project and has a drainage area of 45.17 square kilometers (Soler and others, 1999). Considerable amounts of sediments are transported into Lago Guayo through the tunnel connection. In order to adequately estimate the sediment yield of the Lago Guayo drainage area, the combined drainage areas of both reservoirs (70.03 square kilometers) is needed in the calculations. The sediment accumulation in Lago Guayo (2.63 million cubic meters) divided by the average trapping efficiency of the reservoir (0.97) equals the net quantity of sediment eroded from both basins that affects Lago Guayo. This gives a net 2.71 million cubic meters of sediment in 41 years or 0.07 million cubic meters per year. Based on the combined drainage area of 70.03 square kilometers and assuming a dry-bulk density of 1 gram per cubic centimeter for the sediment, the sediment yield of the Lago Guayo/Lago Yahuecas basin was estimated to be about 857 megagrams per square kilometer per year. 


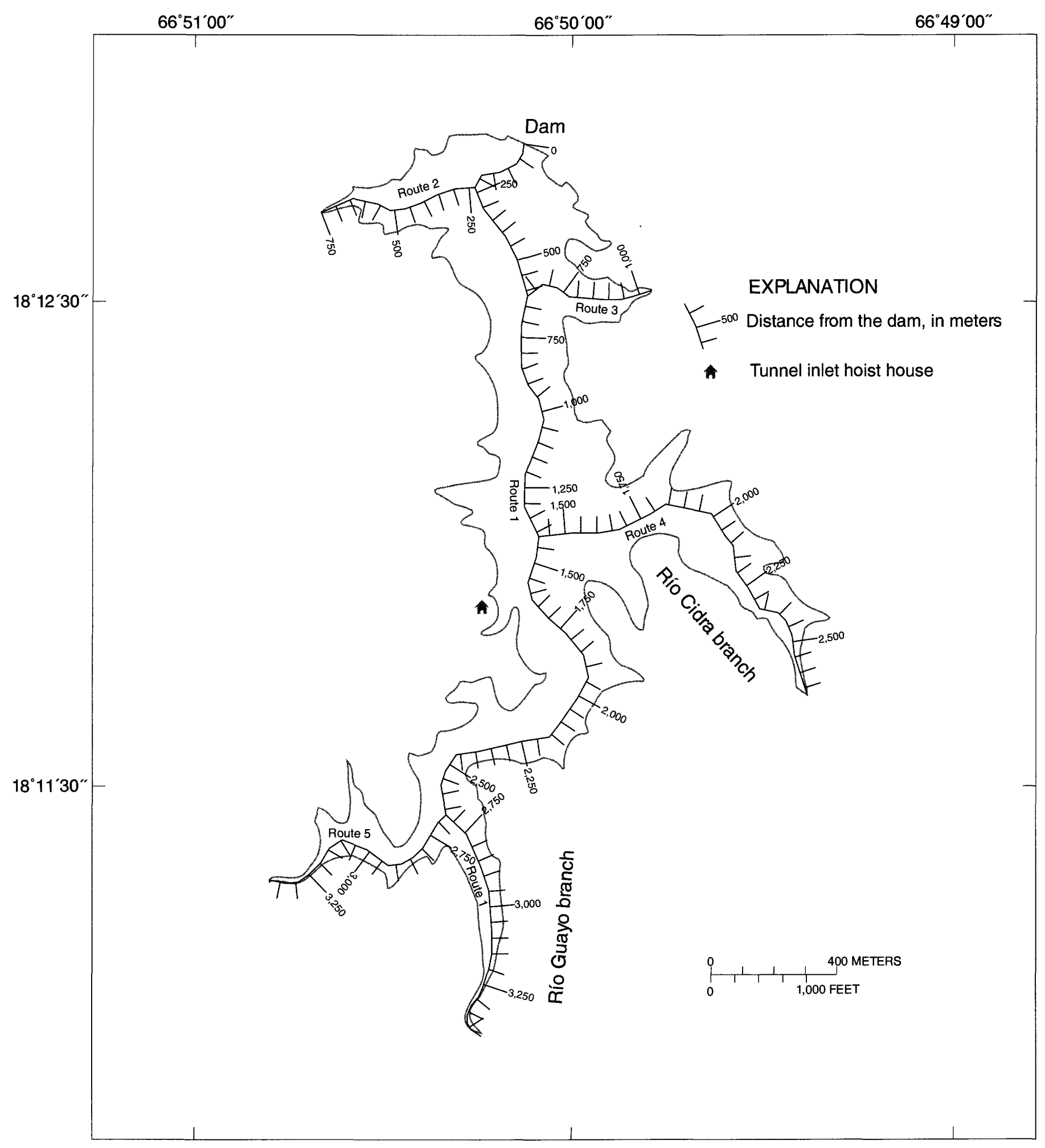

Figure 6. Reference distances for longitudinal profiles of Lago Guayo, Puerto Rico, during the October 1997 bathymetric survey. 

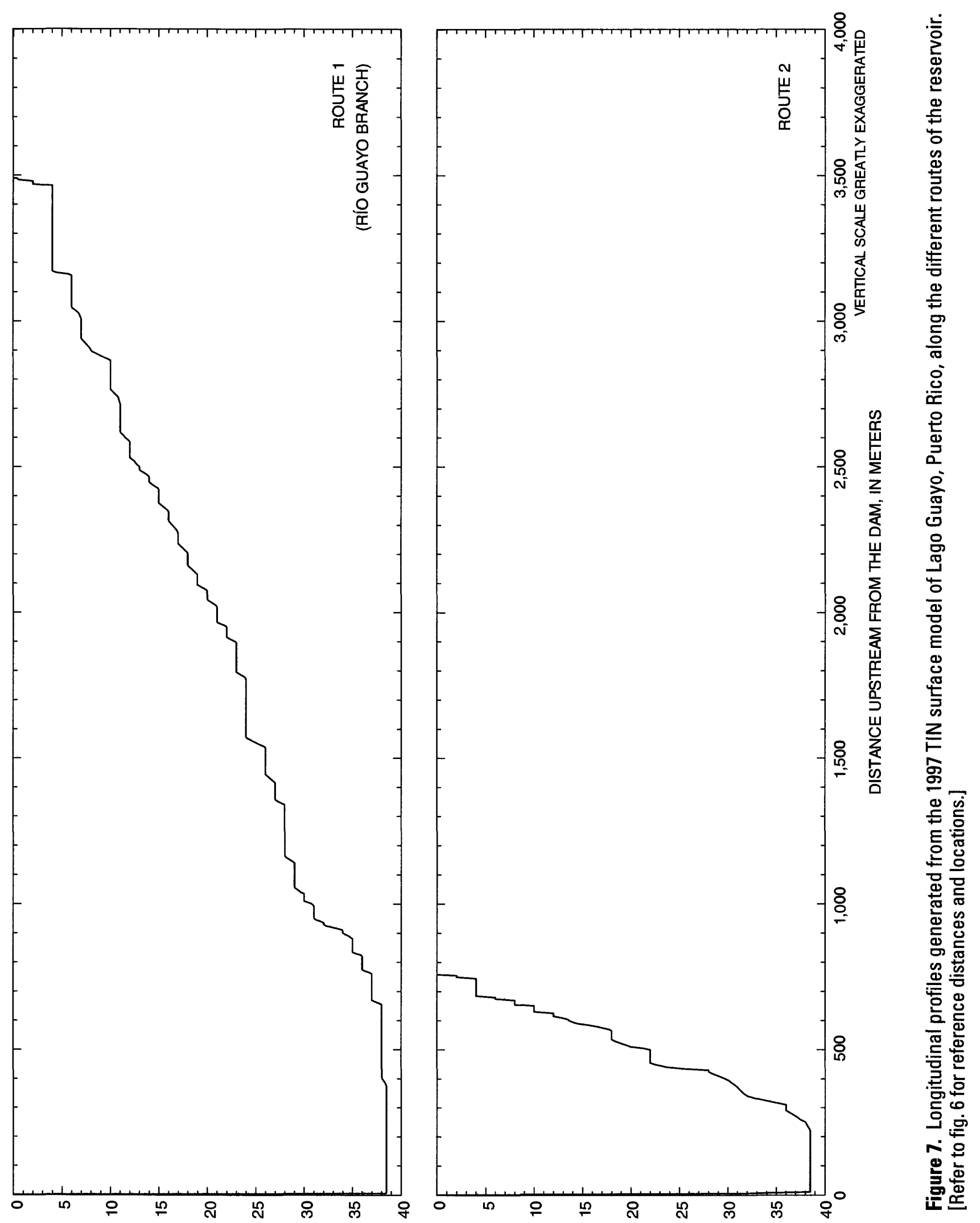

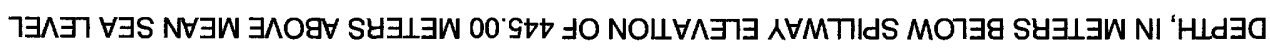



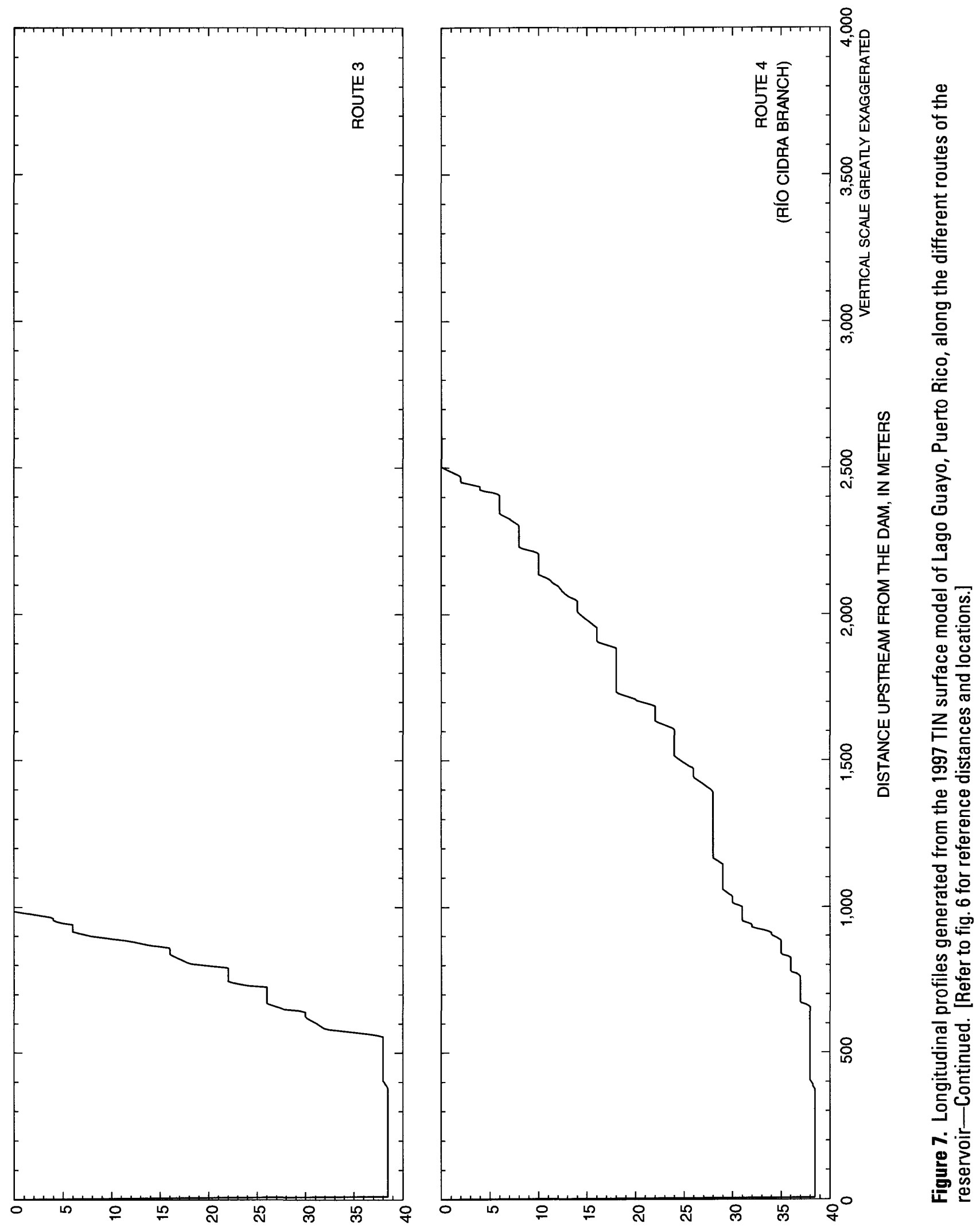

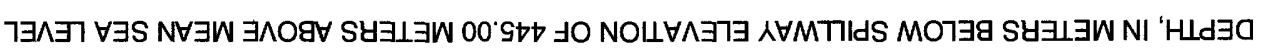




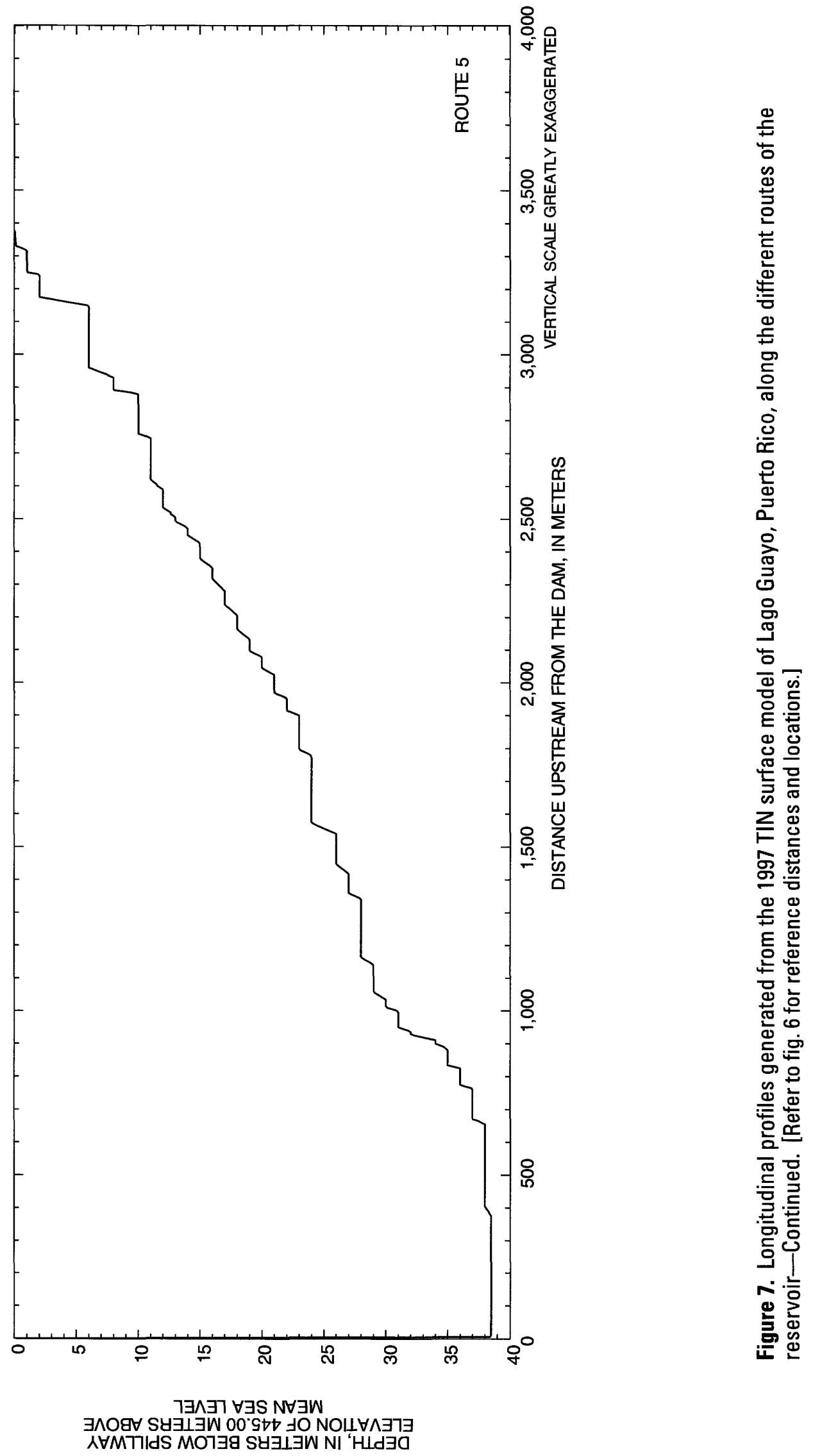




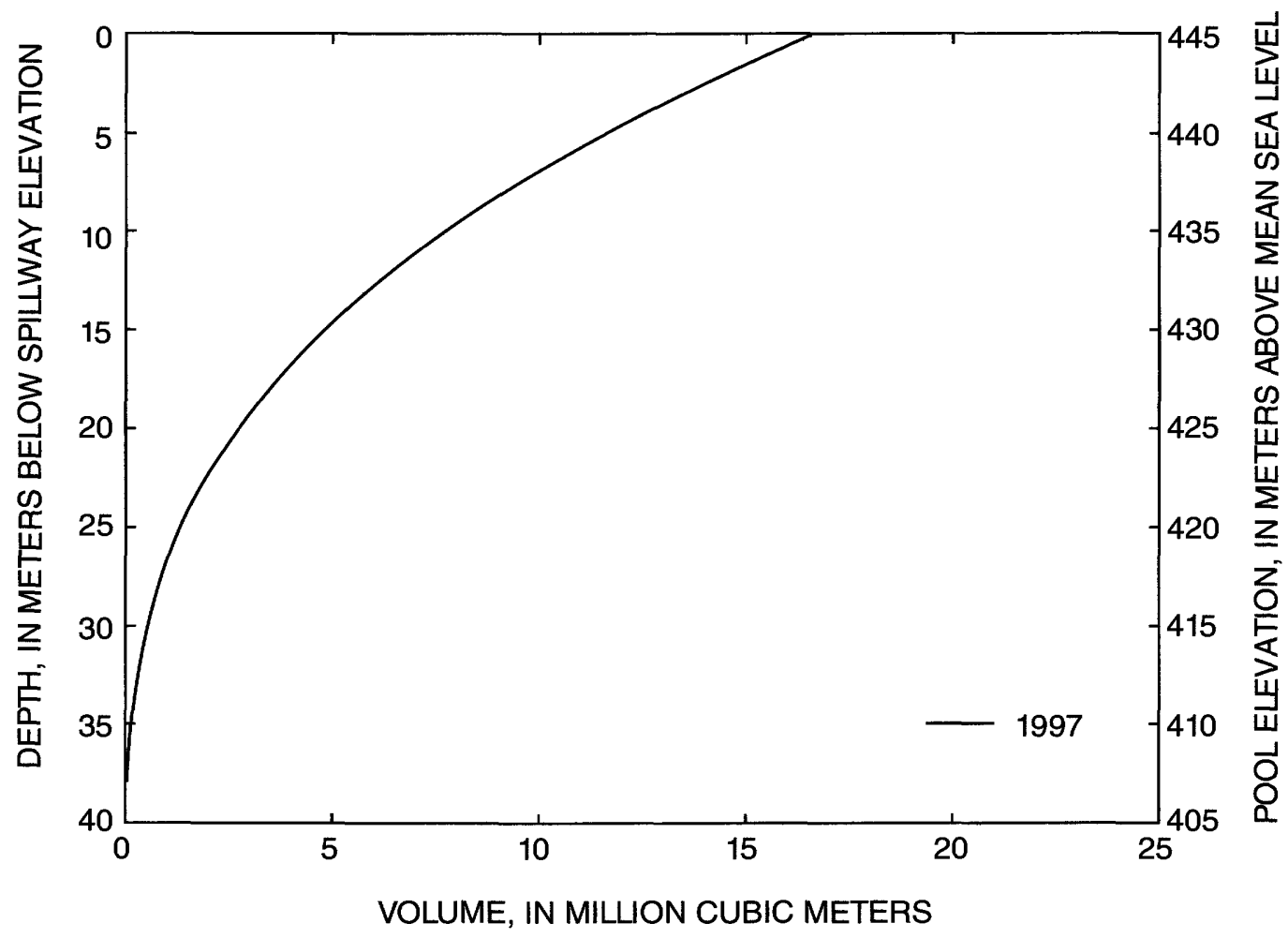

Figure 8. Capacity curve for Lago Guayo, Puerto Rico, for 1997.

\section{REFERENCES}

Brune, G.M., 1953, Trap efficiency of reservoirs:

Transactions of the American Geophysical Union, v. 34, no. 3, p. 407-418.

Calvesbert, R.J., 1970, Climate of Puerto Rico and the U.S. Virgin Islands: U. S. Department of Commerce, Environmental Science Services Administration, $29 \mathrm{p}$.

Giusti, E.V., and López, M.A., 1967, Climate and streamflow of Puerto Rico: Caribbean Journal of Science, v. 7, no. 3-4, September-December 1967 , p. 87-93.

Puerto Rico Water Resources Authority, 1980, Guayo Dam, Adjuntas-Lares, Puerto Rico, Phase 1Inspection Report, Revised: unpublished report, $5 \mathrm{p}$.
Sheda, H.E., and Legas, James, 1968, Condition of concrete dams in Puerto Rico: Section 8, Condition of Guayo Dam, Puerto Rico: Prepared for Puerto Rico Water Resources Authority, Puerto Rico Aqueduct and Sewer Authority by the U.S. Department of Interior, Bureau of Reclamation, 14 p., 5 pls.

Soler-López, L.R., Webb, R.M.T., and Pérez-Blair, Francisco, 1999, Sedimentation survey of Lago Yahuecas, Puerto Rico, March 1997: U.S. Geological Survey Water-Resources Investigations Report 98-4259, 15 p. 

U.S. DEPARTMENT OF THE INTERIOR
science for a changing world
U.S. GEOLOGICAL SURVEY

$66^{\circ} 511^{\prime} 00^{\prime \prime}$
PREPARED IN COOPERATION WITH THE PUERTO RICO ELECTRIC POWER AUTHORITY

WATER-RESOURCES INVESTIGATIONS REPORT 99-4053 Lago Guayo, Puerto Rico, Bathymetry, October 1997-PLATE 1 of 1 Soler-López, L.R., 1999, Sedimentation survey
of Lago Guayo, Puerto Rico, October 1997

$66^{\circ} 49^{\prime} 00^{\prime \prime}$

\section{EXPLANATION}

RESERVOIR BOTTOM CONTOUR-Depth of the reservoir bottom, in 1997 in meters below spillway elevation of 445.00 meters above mean sea level. Contour interval variable. Shoreline shown at spillway elevation of 445.00 meters above mean sea level
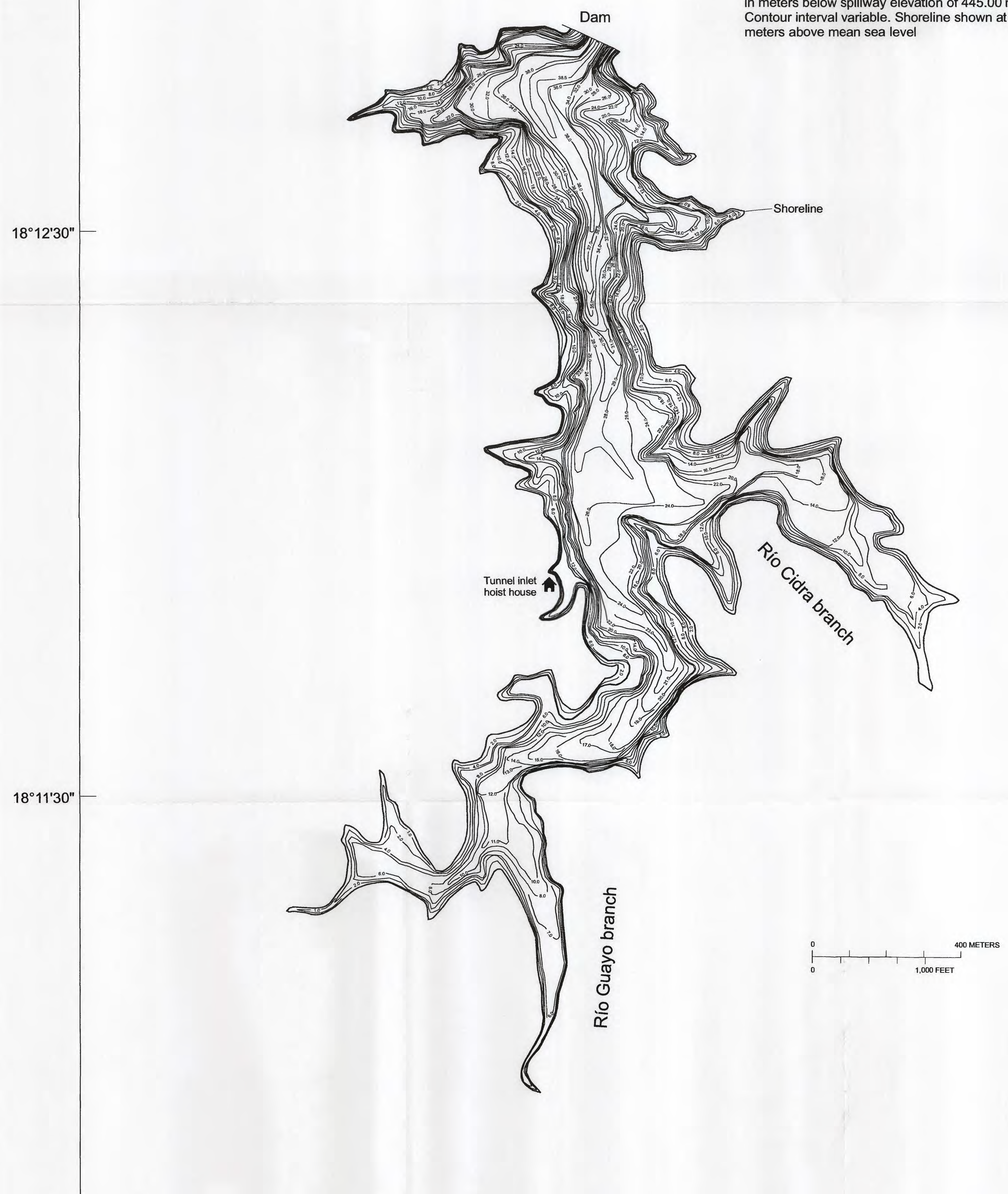